\title{
Bridge to surgery using a self-expandable metallic stent for stages II-III obstructive colorectal cancer
}

\author{
Katsuya Ohta ${ }^{1,2^{*}}$ D, Masakazu Ikenaga ${ }^{1}$, Masami Ueda', Kiyotsugu lede ${ }^{1}$, Yujiro Tsuda', Shinsuke Nakashima', \\ Takashi Nojiri', Jin Matsuyama', Shunji Endo ${ }^{1,4}$, Jun Murata ${ }^{5}$, Ichizo Kobayashi ${ }^{5}$, Masahiko Tsujii ${ }^{5}$ and \\ Terumasa Yamada ${ }^{1}$
}

\begin{abstract}
Background: Bridge to surgery (BTS) using a self-expandable metallic stent (SEMS) for the treatment of obstructive colorectal cancer improves the patient's quality of life. This study aimed to examine prognostic factors of obstructive colorectal cancer.

Methods: We analyzed stage II-III resectable colon cancer cases (Cur A) retrospectively registered between January 2005 and December 2017. Overall, 117 patients with Cur A obstructive colorectal cancer were evaluated: 67 of them underwent emergency surgery (ES Group) and 50 of them after BTS with SEMS placement (BTS group). We compared surgical results and prognoses between the two groups.

Results: A total of 50 patients underwent endoscopic SEMS placement, which technical success of $96 \%$ and morbidity rate of $18 \%$. Primary anastomosis rates were $77.6 \%$ in ES and $95.7 \%$ in BTS $(p<0.001)$; postoperative complication, $46.3 \%$ in ES and $10.5 \%$ in BTS ( $p<0.001$ ); pathological findings of lymphatic invasion, $66.7 \%$ in ES and $100 \%$ in BTS ( $p<0.001$ ); venous invasion were $66.8 \%$ in ES and $92 \%$ in BTS $(p=0.04)$; and recurrence of $25.4 \%$ in ES and $39.1 \%$ in BTS. The 3-year overall survival was significantly different between two groups (ES, 86.8\%:BTS, 58.8\%), BTS is worse than ES (log-rank test; $p<0.001$ ). Venous invasion independently predicted worsened recurrence-free and overall survival.
\end{abstract}

Conclusions: The vascular invasiveness was correlated with tumor progression after SEMS placement, and the survival rate was lower in BTS. SEMS potentially worsens prognostic outcomes in stage II-III obstructive colorectal cancer.

Keywords: Bowel obstruction, Colorectal cancer, Self-expandable metallic stent

\section{Background}

Colorectal cancer $(\mathrm{CRC})$ remains the leading cause of cancer-related deaths worldwide because several patients are initially diagnosed during advanced stages [1].

\footnotetext{
* Correspondence: ohta.k@med.kindai.ac.jp

'Gastroenterological Surgery, Higashiosaka City Medical Center, Osaka, Japan ${ }^{2}$ Department of Gastroenterological Surgery, Kindai University Nara Hospital, 1248-1 Otoda-cho, Ikoma-city, Nara 630-0293, Japan

Full list of author information is available at the end of the article
}

Approximately $8-13 \%$ of patients with CRC were diagnosed with acute colonic obstruction [2-4]. Severe malignancy with bowel obstruction needs urgent surgical intervention, which includes primary lesion resection and stoma creation, leading to increased morbidity and mortality and a potential failure to achieve complete oncological resection $[5,6]$.

An endoscopic procedure with self-expandable metallic stent (SEMS) is an acceptable bridge to surgery (BTS)

(c) The Author(s). 2020 Open Access This article is licensed under a Creative Commons Attribution 4.0 International License, which permits use, sharing, adaptation, distribution and reproduction in any medium or format, as long as you give appropriate credit to the original author(s) and the source, provide a link to the Creative Commons licence, and indicate if changes were made. The images or other third party material in this article are included in the article's Creative Commons licence, unless indicated otherwise in a credit line to the material. If material is not included in the article's Creative Commons licence and your intended use is not permitted by statutory regulation or exceeds the permitted use, you will need to obtain permission directly from the copyright holder. To view a copy of this licence, visit http://creativecommons.org/licenses/by/4.0/ The Creative Commons Public Domain Dedication waiver (http://creativecommons.org/publicdomain/zero/1.0/) applies to the data made available in this article, unless otherwise stated in a credit line to the data. 
treatment for acute colonic obstruction [7-9]. Preoperative SEMS placement provides an opportunity to perform medical resuscitation, comorbidity optimization, bowel preparation, tumor staging, and observation of proximal lesions [10]. The procedure prevents high-risk emergency surgeries and increase oncological resection and primary anastomosis rates $[10,11]$. After the inclusion of colonic SEMS placement as BTS in the coverage of the National Health Insurance in Japan, several physicians joined the Colonic Stent Safety Procedure Research Group and developed skills to provide safe treatment. The largest multicenter prospective study demonstrated the feasibility and safety of SEMS placement as BTS in patients with malignant colorectal obstruction [12].

The oncological safety and minimal invasiveness of this procedure have confirmed that SEMS placement as a bridge to elective surgery is not recommended as a standard treatment for symptomatic left-sided malignant colonic obstruction [13, 14]. Several studies reported that prognostic factors of malignant colonic obstruction in SEMS placement had oncological disadvantages compared with those in emergency surgery (ES) $[15,16]$. In contrast, several trials showed that SEMS placement as a bridge to elective surgery did not improve the survival rates [17-20]. How SEMS placement worsens prognostic outcomes remains unclear [21,22].

This study aimed to evaluate the induction of curative surgery in patients with malignant colorectal obstruction after a SEMS placement and its long-term results and prognostic factors postoperatively compared to patients without SEMS placement. We demonstrated prognostic factors and overall survival (OS) and recurrence-free survival (RFS) rates for curative surgery after a SEMS placement.

\section{Methods}

\section{Patients}

Medical records of patients who underwent primary colorectal resection at Higashiosaka City Medical Center between January 2005 and December 2017 were reviewed. All participants provided written informed consent. Oral intake and symptoms before and after SEMS placement were assessed in Table 1 using the ColoRectal Obstruction Scoring System (CROSS). From 2012 to 2015, we recruited patients with all class of

Table 1 The ColoRectal Obstruction Scoring System (CROSS)

\begin{tabular}{ll}
\hline Patient's symptom and their condition of an oral intake & CROSS \\
\hline Solid meal, low residue, and full diet without symptom & 4 \\
Solid meal, low residue, and full diet with symptom & 3 \\
Liquid or enteral nutrient intake & 2 \\
No oral intake & 1 \\
Requiring continuous decompression & 0 \\
\hline
\end{tabular}

CROSS as stent insertion candidate. From 2015, we excluded patients with CROSS 3 and 4 based on up-dated stent insertion guideline [10]. Malignant colorectal obstruction was diagnosed through clinical examination, CROSS, radiography, and computed tomography. Surgery was performed using three approaches: ES comprised laparotomy, lymph node dissection as possible, and primary anastomosis on the same day between 2005 and 2011. BTS after SEMS placement comprised standby laparoscopy, D3 lymph node dissection, and primary anastomosis since January 2012. Overall, 117 patients with Stage II-III (Cur A) obstructive colorectal cancer were evaluated: 67 of them underwent emergency surgery as ES Group and 50 of them after BTS with SEMS placement as BTS group. We compared surgical results and prognoses between the two groups.

\section{SEMS devices and the procedure}

Patients were endoscopically treated with placement of an uncovered WallFlex enteral colonic stent (Boston Scientific Corporation, Natick, MA, USA) or Niti-S enteral colonic uncovered stent (Taewoong, Inc., Gimpo, South Korea). Placements were performed as presented in the pre-introduction publicity announcement. Placement details were mentioned on the website as a brief guideline [10]. Obstruction structures were determined using a guide wire, and a contrast tube was inserted into the proximal colorectal lumen. Obstructions were measured using contrast agents, and then the endoscopist determined the number, size, and type of stent. Pathological biopsies were recommended after SEMS. Locations and intraluminal or extraluminal marking using an endoscopic clip were recommended via visual recognition of the endoscopist. Dilatation of the colonic obstruction before SEMS placement was generally not allowed.

\section{Histological findings}

Paraffin-embedded specimens were obtained from a cohort of 117 patients diagnosed by the Union for International Cancer Control stage II-III.

\section{Survival definitions}

OS was defined as the duration from surgery to any death or last follow-up. Diagnosis of recurrence was calculated based on RECIST 1.1 according to the chemotherapy criteria [23]. RFS was defined as the duration from surgery to any recurrence includes local recurrence or distant metastasis.

\section{Statistical analysis}

Student's $t$-test and Wilcoxon test for continuous variables and the $\chi^{2}$ and Fisher's exact tests for categorical variables were conducted. Survival curves were generated using the Kaplan-Meier method and compared 
Table 2 Baseline characteristics and outcomes of endoscopic SEMS placement

\begin{tabular}{|c|c|c|}
\hline & & BTS $(n=50)$ \\
\hline Gender & Male/Female & $22 / 28$ \\
\hline Age & Median (range) & $73(44-90)$ \\
\hline \multirow[t]{6}{*}{ Location } & Cecum & 0 \\
\hline & Ascending & 8 \\
\hline & Transverse & 8 \\
\hline & Descending & 6 \\
\hline & Sigmoid & 20 \\
\hline & Rectum & 8 \\
\hline Length of obstruction & Median (range; cm) & $3(2-8)$ \\
\hline Technical success & & $48(96 \%)$ \\
\hline \multirow[t]{2}{*}{ Procedure } & Through the scope & 42 \\
\hline & Through the wire & 6 \\
\hline \multirow[t]{2}{*}{ Stenting } & Wall Flex $6 / 9 \mathrm{~cm}$ & $33 / 3$ \\
\hline & Niti-S 6/ 8/ $10 \mathrm{~cm}$ & 7/4/ 1 \\
\hline \multirow[t]{2}{*}{ Morbidity } & Overall & $5(18 \%)$ \\
\hline & $>C-D^{a} \| I$ & $1(2 \%)$ \\
\hline Mortality & $C-D^{a} V$ & $1(2 \%)$ \\
\hline \multirow[t]{7}{*}{ Clinical success } & & $46(92 \%)$ \\
\hline & CROSS & Before / After \\
\hline & 4 & $1 / 46$ \\
\hline & 3 & $13 / 0$ \\
\hline & 2 & $4 / 2$ \\
\hline & 1 & $14 / 1$ \\
\hline & 0 & 18/ 1 \\
\hline
\end{tabular}

${ }^{a}$ Clavien-Dindo classification

using a log-rank test. Univariate and multivariate survival analyses were performed using the Cox proportional hazards regression model. All statistical analyses used JMP (version 8.01, SAS Institute, Cary, NC) or statistical scripting language R (http;//www.r-project.org/). $P$-values of $\leq 0.05$ (two-sided) were considered statistically significant. This prognostic study complied with the reporting recommendations for Tumor Marker Prognostic Studies [24].

\section{Results}

A total of 50 patients underwent endoscopic SEMS placement, which was technically safe for malignant colorectal obstruction, with the technical success rate of $96 \%$. The clinical success rate was $92 \%$, and the patient's symptoms and oral intake dramatically improved after the SEMS placement, shown in Table 2. A total of 117 patients were reviewed: 67 and 50 patients underwent ES and BTS, respectively, as shown in Table 3. Baseline clinical characteristics were balanced between the two groups. Moreover, $79.1 \%$ (53 cases) of patients underwent ES on the same day as in open surgery. The median waiting period for surgery was 14 days for BTS. The
Table 3 Comparison of baseline characteristics in patients undergoing emergency surgery and bridge to surgery

\begin{tabular}{|c|c|c|c|c|}
\hline & & $\mathrm{ES}(n=67)$ & $\begin{array}{l}\text { BTS }(n= \\
50)\end{array}$ & $p$ \\
\hline Gender & Male/Female & $35 / 32$ & $22 / 28$ & 0.377 \\
\hline Age & Median (range) & 69 (33-93) & $73(44-90)$ & 0.106 \\
\hline \multirow[t]{6}{*}{ Location } & Cecum & 0 & 0 & \multirow[t]{6}{*}{0.657} \\
\hline & Ascending & 6 & 8 & \\
\hline & Transverse & 10 & 8 & \\
\hline & Descending & 14 & 6 & \\
\hline & Sigmoid & 25 & 20 & \\
\hline & Rectum & 12 & 8 & \\
\hline \multirow[t]{2}{*}{ Type of operation } & Standby & $14(21 \%)$ & $44(88 \%)$ & \multirow{2}{*}{$\begin{array}{l}< \\
0.001\end{array}$} \\
\hline & Emergency & $53(79 \%)$ & $6(12 \%)$ & \\
\hline $\begin{array}{l}\text { Duration to } \\
\text { operation }\end{array}$ & Median (range; days) & $0(0-27)$ & $14(0-67)$ & $\begin{array}{l}< \\
0.001\end{array}$ \\
\hline \multirow[t]{2}{*}{ Surgical Procedure } & Laparotomy & $67(100 \%)$ & $21(39 \%)$ & \multirow[t]{2}{*}{-} \\
\hline & Laparoscopy & 0 & $29(61 \%)$ & \\
\hline \multirow[t]{2}{*}{ Time } & \multirow[t]{2}{*}{ Median (range; min) } & 203 & 215 & \multirow[t]{2}{*}{0.808} \\
\hline & & $(123-508)$ & $(99-648)$ & \\
\hline Blood loss & Median (range; mL) & $\begin{array}{l}324(0- \\
526)\end{array}$ & $69(0-2495)$ & $\begin{array}{l}< \\
0.001\end{array}$ \\
\hline Stoma creation & & $15(22 \%)$ & $3(14 \%)$ & $\begin{array}{l}< \\
0.001\end{array}$ \\
\hline \multirow[t]{3}{*}{ Morbidity } & 30-day complication & $31(46 \%)$ & $5(10 \%)$ & $\begin{array}{l}< \\
0.001\end{array}$ \\
\hline & $>C-D^{a} \| I$ & $6(9 \%)$ & $2(4 \%)$ & $\begin{array}{l}< \\
0.001\end{array}$ \\
\hline & $\begin{array}{l}\text { Anastomostic } \\
\text { leakage }\end{array}$ & $4(22 \%)$ & $1(2 \%)$ & $<0.001$ \\
\hline Hospital Stay & Median (range; days) & $17(6-120)$ & $11(7-140)$ & 0.002 \\
\hline
\end{tabular}

${ }^{a}$ Clavien-Dindo classification

primary anastomosis ratios were $77.6 \%$ in ES and $95.7 \%$ in BTS $(p<0.001)$. Postoperative complication rates were $46.3 \%$ in ES and $10.5 \%$ in BTS $(p<0.001)$. Postoperative hospital stay was shorter in BTS (11 days) compared to ES (17 days) $(p=0.002)$. Patients with obstructive CRC showed significant improvement in postoperative complication rate and hospital stay with SEMS placement. Operative procedures were dramatically changed, and the primary anastomosis rate improved after the SEMS placement.

The pathological tissue type accounted for $96.4 \%$ of differentiated types shown in Table 4. Tumor depth was similar between the two groups. Lymphatic vessel invasion ratios were $66.7 \%$ in ES and $100 \%$ in BTS $(p<0.001)$, and venous invasion ratios were $66.8 \%$ in ES and $92 \%$ in BTS $(p=0.038)$. Recurrence rates were $25.4 \%$ (17 cases) in ES and 39.1\% (18 cases) in BTS. Node-negative patients (stage II) more frequently had lung metastasis (54.5\%), whereas node-positive patients (stage III) more frequently had liver metastasis (41.7\%). In the KaplanMeier survival analysis in Fig. 1a, the 3-year RFS was 
Table 4 Comparison of pathological characteristics of emergency surgery and bridge to surgery

\begin{tabular}{|c|c|c|c|c|}
\hline & & $\mathrm{ES}(n=67)$ & BTS $(n=50)$ & $p$ \\
\hline pT factor & $\mathrm{T} 4 \mathrm{~b} / \mathrm{T} 4 \mathrm{a} / \mathrm{T3}$ & $12 / 16 / 39$ & $3 / 11 / 36$ & 0.131 \\
\hline Total Lymph nodes & Median (range) & $16(3-52)$ & $21(4-58)$ & 0.062 \\
\hline pN factor & N0/ N1/ N2/ N3 & $37 / 20 / 7 / 3$ & 19/17/13/ 1 & 0.134 \\
\hline Histological & tub1/ tub2/ others & $12 / 51 / 4$ & $15 / 35 / 0$ & 0.126 \\
\hline Lymphatic invasion & ly $0 / 1 / 2 / 3$ & $21 / 33 / 14 / 0$ & $0 / 29 / 16 / 5$ & $<0.001$ \\
\hline Venous invasion & $\vee 0 / 1 / 2 / 3$ & $14 / 31 / 22 / 1$ & $4 / 23 / 17 / 6$ & 0.038 \\
\hline Surgical clearance & Cur A/ B/ C & $67 / 0 / 0$ & $50 / 0 / 0$ & - \\
\hline
\end{tabular}

significantly different between the two groups (ES, $76.6 \%$; BTS, 59.4\%), which was significantly low in BTS than that in ES (log-rank test; $p=0.003$ ). The 3 -year OS rate was also significantly different between the two groups: ES, 86.8\%; BTS, 58.8\%; $p<0.001$, shown in Fig. $1 \mathrm{~b}$. The relationship between lymph node metastasis and SEMS placement was also evaluated. The pathological node-negative (stage II) 3-year RFS rate was not different between the two groups (ES, 81.6\%; BTS, 75.0\%) as shown in Fig. 2a. In contrast, the pathological node-positive (stage III) 3-year RFS rate was different between the two groups (ES, 70.7\%; BTS, 49.8\%) as shown in Fig. 2b. The stage II 3-year OS rate was not different between the two groups (ES, 81.6\%; BTS, 75.0\%) as shown in Fig. 2c, whereas stage III 3-year OS rate was different between the two groups (ES, 70.7\%; BTS, 49.8\%) as shown in Fig. 2d. These results suggest that vascular invasiveness and pathological node-positive status were correlated with tumor progression after SEMS placement; thus, the survival rate was affected by poor prognosis in the BTS group.

Results of adjusted multiple Cox proportional hazard regression for RFS and OS in all stages and stage III disease are presented in Table 5. After adjusting for possible confounders, venous invasion and BTS independently predicted poor RFS in all stages, and venous invasion independently predicted poor RFS in stage III disease. Venous invasion and BTS were also significantly associated with OS in stage III disease.

\section{Discussion}

Acute colonic obstruction requires emergent surgical intervention, a mandatory conventional treatment skill. Emergent surgical treatment is associated with high morbidity, mortality, and stoma creation rates, affecting the quality of life of patients. Malignant colorectal obstruction is not only an intestinal obstruction but also an advanced stage CRC. Their prognosis was poorer than that in patients with non-occlusive disease because

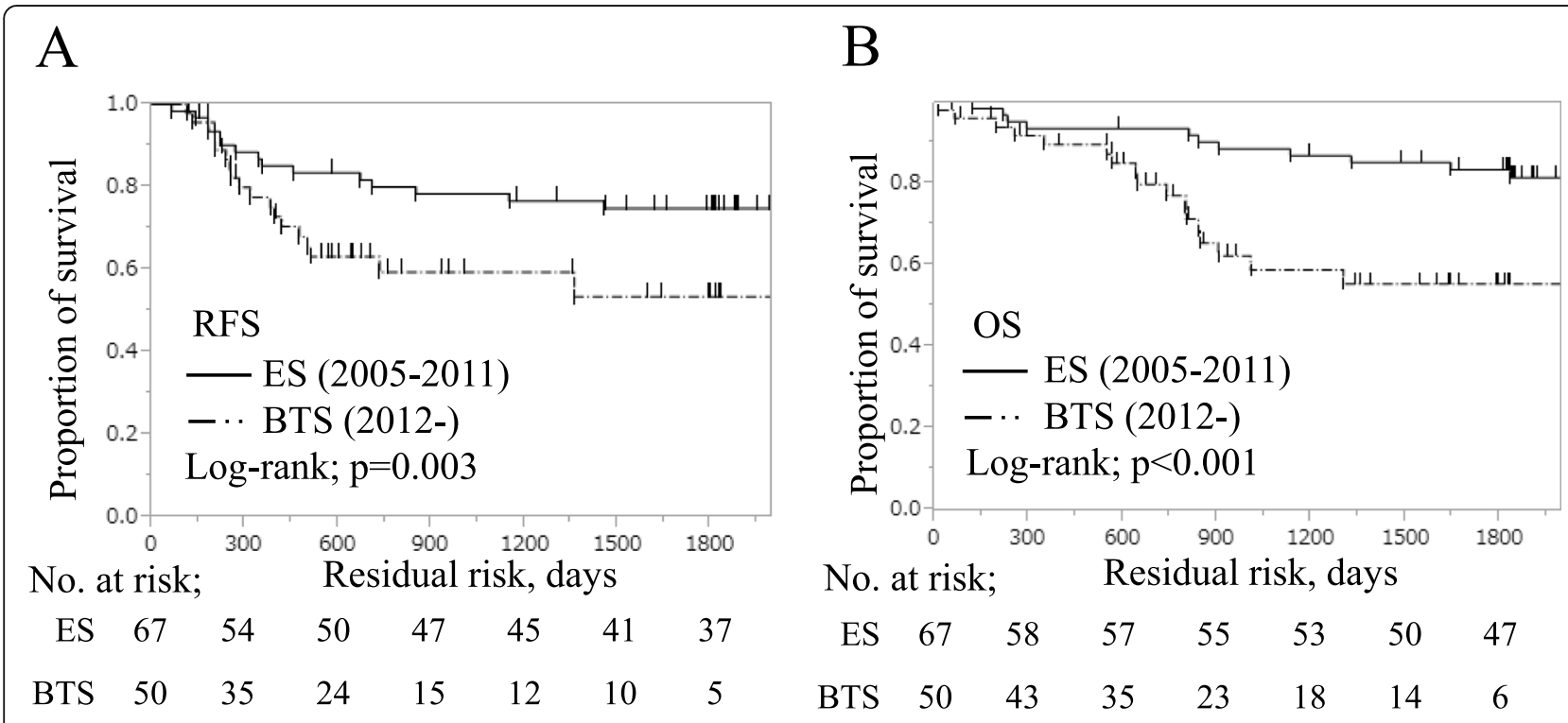

Fig. 1 Kaplan-Meier survival curves in patients undergoing emergency surgery vs. bridge to surgery. a Recurrence-free survival. b Overall survival 


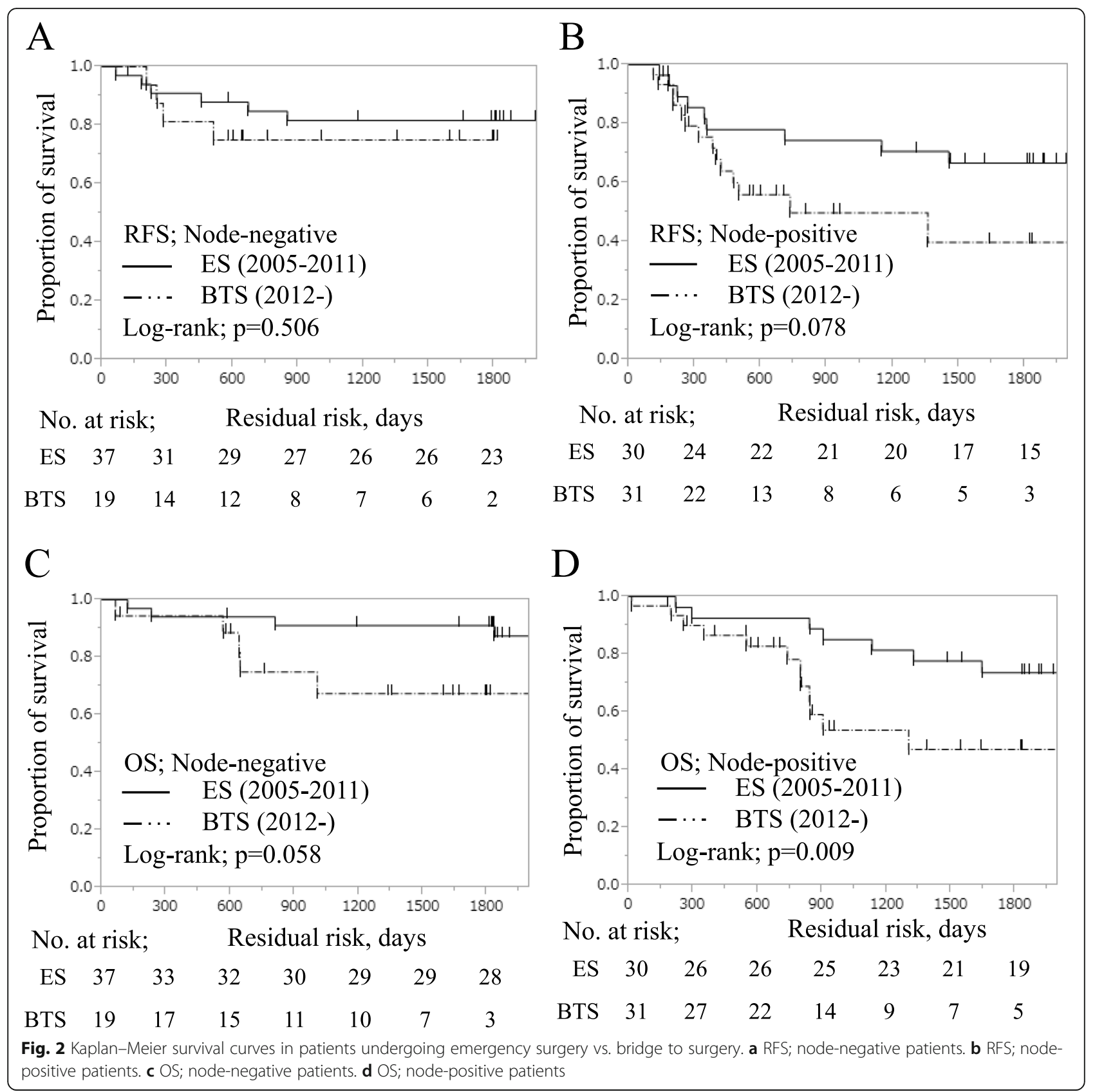

of highly invasiveness and distant metastasis [25, 26]. Chen et al. revealed that the prognosis in patients with perforation associated with obstruction was poor [13]. Early intervention in the clinical setting before the colonic perforation has been established. Endoscopic placement of colonic stents improves the high decompression effect and reduces clinical symptoms [10].

High postoperative complication rates were correlated with poor prognosis in patients with cancer in several organs [27-30]. Reducing complication rates can improve the prognosis. Our results showed high clinical success rate after SEMS placement and high primary anastomosis rate. Stent-related complications required emergent surgical interventions; however, the stent placement is safe and feasible in this study. Moreover, the laparoscopic rate was high, and postoperative complication rate was $10 \%$. Clinical results, including shortterm outcomes in BTS after SEMS, were verified through a meta-analysis $[9,10,15]$.

The prognosis was poor in patients with stent perforation and increased local recurrence rate after the colonic stent placement [20]. However, the long-term prognosis in patients with colorectal obstruction after BTS was not different compared with that in patients 
Table 5 Multivariate analysis of recurrence-free survival at all Stages and Stage III

\begin{tabular}{|c|c|c|c|c|}
\hline Variables & All Stages Hazard ratio \pm SD $(95 \%$ Cl) & $p$-value & Stage III Hazard ratio \pm SD $(95 \%$ Cl) & $p$-value \\
\hline \multicolumn{5}{|l|}{ Recurrence free suvival } \\
\hline ES vs SEMS & HR $0.42 \pm 0.20(0.03,0.82)$ & 0.036 & HR $0.45 \pm 0.26(-0.04,0.98)$ & 0.071 \\
\hline pT factor; T3/T4 & $H R-0.55 \pm 0.25(-1.03,-0.06)$ & 0.089 & $H R-0.51 \pm 0.31(-1.13,0.13)$ & 0.258 \\
\hline pN factor; N0/N1/N2-3 & $H R-0.39 \pm 0.29(-0.97,0.14)$ & 0.364 & $H R-0.03 \pm 0.23(-0.49,-0.43)$ & 0.891 \\
\hline Verous invasion (v0-1/v2-3) & $H R-0.57 \pm 0.19(-0.96,-0.21)$ & 0.002 & $H R-0.59 \pm 0.24(-1.11,-0.14)$ & 0.001 \\
\hline Lymphatic invasion (ly0-1/ly2-3) & HR $0.19 \pm 0.22(-0.24,0.64)$ & 0.396 & HR $0.01 \pm 0.24(-0.40,0.56)$ & 0.752 \\
\hline \multicolumn{5}{|l|}{ Overall suvival } \\
\hline ES vs SEMS & HR $0.86 \pm 0.22(0.42,1.32)$ & $<0.001$ & HR $0.99 \pm 0.31(0.40,1.64)$ & $<0.001$ \\
\hline pT factor; T3/T4 & $H R-0.86 \pm 0.28(-1.41,0.31)$ & 0.007 & $\mathrm{HR}-1.21 \pm 0.40(-2.03,-0.42)$ & 0.019 \\
\hline pN factor; N0/N1/N2-3 & $H R-0.40 \pm 0.30(-1.01,0.18)$ & 0.358 & $H R-0.01 \pm 0.24(-0.49,-0.49)$ & 0.976 \\
\hline Verous invasion (v0-1/v2-3) & $H R-0.37 \pm 0.20(-0.77,-0.02)$ & 0.065 & $H R-0.57 \pm 0.27(-1.13,-0.07)$ & 0.025 \\
\hline Lymphatic invasion (ly0-1/ly2-3) & HR $0.21 \pm 0.23(-0.23,0.69)$ & 0.348 & HR $0.29 \pm 0.26(-0.21,0.81)$ & 0.253 \\
\hline
\end{tabular}

without obstruction [31-34]. According to the European Society of Gastrointestinal Endoscopy clinical guideline that considers the risk of perforation due to colorectal stents, only limited uses are allowed; therefore, colorectal stent placement is not a standard treatment [35-38]. The prognostic outcomes of BTS in this study were significantly worse than those of ES. Particularly, in lymph node-positive patients, lymphatic and venous invasion seemed to be a significant prognostic factor. Although reduced postoperative complication rate would improve the prognosis, our results were contradictory after the stent replacement. These results suggested that stent placement leads to poor prognosis. A concern that colonic stents may be associated with adverse effects of mechanical expansion also exists [39, 40]. Mechanical expansion may be associated with the growth of solid tumors, particularly lymphatic and venous invasion $[41,42]$.

We found that recurrence and OS were associated with high vascular invasion after a colonic stent placement. Venous invasion was an independent factor for recurrence and prognosis. The CK20 mRNA level, an epithelial marker, is significantly increased in peripheral blood serum, suggesting stent deployment into the vasculature [43]. Alliteratively, Ki-67 level, associated with cellular proliferation, and p27 gene, assisting cell cycle progression, were measured using specimens obtained before and after SEMS insertion; next, the Ki-67 level decreased in the specimen after an SEMS placement compared with that before, and cell proliferation was suppressed [44]. The prognostic nutritional index and serum albumin levels were significantly decreased after stenting, suggesting its disadvantage as BTS [45]. The duration from stent placement to surgery was 14 days. Oncological and nutritional factors might change in the blood and contribute to poor prognosis during the waiting period. Mechanical expansion of the replacement should be minimized to prevent perforation and molecular cytological factors. To improve the materials, expansion and establishment of new mechanism are necessary in colorectal obstruction [46, 47].

These findings should be considered in light of several limitations. First, this is a retrospective, nonrandomized, small sample sized study from a single institution; thereby, the heterogeneity of the surgical strategy may have affected the prognostic factors. Second, although validated endoscopic procedures were validated, stent devices used in this study had different lengths, types, and thickness and obtained from different vendors. Lastly, we performed stent placement in the patients with CROSS 3 and 4 who are not indicated for stent insertion until 2015.

To investigate the oncological long-term prognosis of colonic SEMS placement as a bridge to elective surgery, large sample size and prospective randomized controlled studies are warranted to develop a treatment strategy for CRC with obstruction.

\section{Conclusion}

Vascular invasiveness was correlated with tumor progression after a SEMS placement, and OS and RFS rates were lower in BTS. SEMS placement potentially worsens prognostic outcomes in stage II-III malignant colorectal obstruction.

\section{Abbreviations}

BTS: Bridge to surgery; CRC: Colorectal cancer; CROSS: ColoRectal Obstruction Scoring System; ES: Emergency surgery; ESGE: European Society of

Gastrointestinal Endoscopy; JSCCR: Japanese Society for Cancer of the Colon and Rectum; RECIST 1.1: Response Evaluation Criteria in Solid Tumors, version 1.1; OS: Overall survival; RFS: Recurrence-free survival; SEMS: Self-expandable metallic stent; WSES: World society of emergency surgery

\section{Acknowledgements}

The authors thank for contribution as endoscopic technical adviser: Ken Konishi M.D., Ph.D. from Department of Surgery, Hyogo Prefecture Nishinomiya Hospital. 


\section{Authors' contributions}

All authors have read and approved the manuscript. KO: protocol/ project development, data collection and management, and manuscript writing/editing. MI: protocol/project development, management, and manuscript writing/editing. MU: protocol/project development and data collection and management. JM, SE, JM, and IK: data collection and management. YT and SN: data collection. KI and TN: data analysis and manuscript writing/editing. MT and TY: data analysis and management.

\section{Funding}

Authors have no grant support and no financial relationship for this study.

\section{Availability of data and materials}

The datasets used and analyzed during this study are available from the corresponding author upon reasonable request.

\section{Ethics approval and consent to participate}

All procedures performed in studies involving human participants were in accordance with the ethical standards of the Institutional Research Committee and with the 1964 Helsinki Declaration and its later amendments or with comparable ethical standards. All participants or their guardians have provided their written informed consent and that the study protocol was approved by Higashiosaka City Medical Center Ethical Committee on human research (assignment number 02-0387).

\section{Consent for publication}

No applicable.

\section{Competing interests}

The Authors declare that they have no conflict of interest to disclose.

\section{Author details}

${ }^{1}$ Gastroenterological Surgery, Higashiosaka City Medical Center, Osaka, Japan. 2Department of Gastroenterological Surgery, Kindai University Nara Hospital, 1248-1 Otoda-cho, Ikoma-city, Nara 630-0293, Japan. ${ }^{3}$ Thoracic Surgery, Higashiosaka City Medical Center, Osaka, Japan. ${ }^{4}$ Digestive Surgery, Kawasaki Medical School, Okayama, Japan. ${ }^{5}$ Gastroenterology, Higashiosaka City Medical Center, Osaka, Japan.

Received: 4 June 2020 Accepted: 12 August 2020

Published online: 20 August 2020

\section{References}

1. Jemal A, Bray F, Center MM, Ferlay J, Ward E, Forman D. Global cancer statistics. CA Cancer J Clin. 2011;61(2):69-90 PubMed PMID: 21296855. Epub 2011/02/08. eng.

2. Winner M, Mooney SJ, Hershman DL, Feingold DL, Allendorf JD, Wright JD, et al. Incidence and predictors of bowel obstruction in elderly patients with stage IV colon cancer: a population-based cohort study. JAMA Surg. 2013; 148(8):715-22 PubMed PMID: 23740130. Pubmed Central PMCID: PMC45 07521. Epub 2013/06/07. eng.

3. Jullumstro E, Wibe A, Lydersen S, Edna TH. Colon cancer incidence, presentation, treatment and outcomes over 25 years. Color Dis. 2011;13(5): 512-8 PubMed PMID: 20128833. Epub 2010/02/05. eng.

4. Cheynel N, Cortet M, Lepage C, Benoit L, Faivre J, Bouvier AM. Trends in frequency and management of obstructing colorectal cancers in a welldefined population. Dis Colon Rectum. 2007;50(10):1568-75 PubMed PMID: 17687610. Epub 2007/08/10. eng.

5. Cuffy M, Abir F, Audisio RA, Longo WE. Colorectal cancer presenting as surgical emergencies. Surg Oncol. 2004;13(2-3):149-57 PubMed PMID: 155 72097. Epub 2004/12/02. eng.

6. McArdle CS, Hole DJ. Emergency presentation of colorectal cancer is associated with poor 5-year survival. Br J Surg. 2004;91(5):605-9 PubMed PMID: 15122613. Epub 2004/05/04. eng.

7. Mainar A, Tejero E, Maynar M, Ferral H, Castaneda-Zuniga W. Colorectal obstruction: treatment with metallic stents. Radiology. 1996;198(3):761-4 PubMed PMID: 8628867. Epub 1996/03/01. eng.

8. Zhang Y, Shi J, Shi B, Song CY, Xie WF, Chen YX. Comparison of efficacy between uncovered and covered self-expanding metallic stents in malignant large bowel obstruction: a systematic review and meta-analysis.
Color Dis. 2012;14(7):e367-74 PubMed PMID: 22540666. Epub 2012/05/01. eng.

9. Tilney HS, Lovegrove RE, Purkayastha S, Sains PS, Weston-Petrides GK, Darzi AW, et al. Comparison of colonic stenting and open surgery for malignant large bowel obstruction. Surg Endosc. 2007;21(2):225-33 PubMed PMID: 17160651. Epub 2006/12/13. eng.

10. Saito S, Yoshida S, Isayama H, Matsuzawa T, Kuwai T, Maetani I, et al. A prospective multicenter study on self-expandable metallic stents as a bridge to surgery for malignant colorectal obstruction in Japan: efficacy and safety in 312 patients. Surg Endosc. 2016;30(9):3976-86 PubMed PMID: 26684205. Epub 2015/12/20. eng.

11. Saida $Y$, Sumiyama $Y$, Nagao J, Uramatsu M. Long-term prognosis of preoperative "bridge to surgery" expandable metallic stent insertion for obstructive colorectal cancer: comparison with emergency operation. Dis Colon Rectum. 2003;46(10 Suppl):S44-9 PubMed PMID: 14530657. Epub 2003/10/08. eng.

12. Tomita M, Saito S, Makimoto S, Yoshida S, Isayama H, Yamada T, et al. Selfexpandable metallic stenting as a bridge to surgery for malignant colorectal obstruction: pooled analysis of 426 patients from two prospective multicenter series. Surg Endosc. 2019;33(2):499-509 PubMed PMID: 3000684 0. Pubmed Central PMCID: PMC6342866. Epub 2018/07/15. eng.

13. Chen HS, Sheen-Chen SM. Obstruction and perforation in colorectal adenocarcinoma: an analysis of prognosis and current trends. Surgery. 2000; 127(4):370-6 PubMed PMID: 10776426. Epub 2000/04/25. eng.

14. Huang X, Lv B, Zhang S, Meng L. Preoperative colonic stents versus emergency surgery for acute left-sided malignant colonic obstruction: a meta-analysis. J Gastrointest Surg. 2014;18(3):584-91 PubMed PMID: 241706 06. Epub 2013/10/31. eng.

15. Kim HJ, Huh JW, Kang WS, Kim CH, Lim SW, Joo YE, et al. Oncologic safety of stent as bridge to surgery compared to emergency radical surgery for left-sided colorectal cancer obstruction. Surg Endosc. 2013;27(9):3121-8 PubMed PMID: 23436100. Epub 2013/02/26. eng.

16. Shigeta K, Baba H, Yamafuji K, Kaneda H, Katsura H, Kubochi K. Outcomes for patients with obstructing colorectal cancers treated with one-stage surgery using transanal drainage tubes. J Gastrointest Surg. 2014;18(8):150713 PubMed PMID: 24871080. Epub 2014/05/30. eng.

17. van Hooft JE, Bemelman WA, Oldenburg B, Marinelli AW, Lutke Holzik MF, Grubben MJ, et al. Colonic stenting versus emergency surgery for acute leftsided malignant colonic obstruction: a multicentre randomised trial. Lancet Oncol. 2011;12(4):344-52 PubMed PMID: 21398178. Epub 2011/03/15. eng.

18. van Hooft JE, Fockens P, Marinelli AW, Timmer R, van Berkel AM, Bossuyt PM, et al. Early closure of a multicenter randomized clinical trial of endoscopic stenting versus surgery for stage IV left-sided colorectal cancer. Endoscopy. 2008;40(3):184-91 PubMed PMID: 18322873. Epub 2008/03/07. eng.

19. Sloothaak DA, van den Berg MW, Dijkgraaf MG, Fockens $P$, Tanis PJ, van Hooft JE, et al. Oncological outcome of malignant colonic obstruction in the Dutch stent-in 2 trial. Br J Surg. 2014;101(13):1751-7 PubMed PMID: 252 98250. Epub 2014/10/10. eng.

20. Gorissen KJ, Tuynman JB, Fryer E, Wang L, Uberoi R, Jones OM, et al. Local recurrence after stenting for obstructing left-sided colonic cancer. $\mathrm{Br} J$ Surg. 2013;100(13):1805-9 PubMed PMID: 24227368. Epub 2013/11/15. eng.

21. Ormando VM, Palma R, Fugazza A, Repici A. Colonic stents for malignant bowel obstruction: current status and future prospects. Expert Rev Med Devices. 2019;16(12):1053-61 PubMed PMID: 31778081. Epub 2019/11/30. eng.

22. Lauro A, Binetti M, Vaccari S, Cervellera M, Tonini V. Obstructing left-sided colonic Cancer: is endoscopic stenting a bridge to surgery or a bridge to nowhere? Digestive diseases and sciences. 2020. PubMed PMID: 32583222. Epub 2020/06/26. eng.

23. Schwartz LH, Litière S, de Vries E, Ford R, Gwyther S, Mandrekar S, et al. RECl ST 1.1-Update and clarification: From the RECIST committee. European journal of cancer (Oxford, England: 1990); 2016. p. 132-7. PubMed PMID: 27189322. Pubmed Central PMCID: PMC5737828. Epub 2016/05/18. eng.

24. McShane LM, Altman DG, Sauerbrei W, Taube SE, Gion M, Clark GM. REporting recommendations for tumour MARKer prognostic studies (REMARK). Eur J Cancer. 2005;41(12):1690-6 PubMed PMID: 16043346. Epub 2005/07/27. eng.

25. Hashiguchi Y, Muro K, Saito Y, Ito Y, Ajioka Y, Hamaguchi T, et al. Japanese Society for Cancer of the Colon and Rectum (JSCCR) guidelines 2019 for the treatment of colorectal cancer. Int J Clin Oncol. 2019;15 PubMed PMID: 312 03527. Epub 2019/06/17. eng.

26. Cortet M, Grimault A, Cheynel N, Lepage C, Bouvier AM, Faivre J. Patterns of recurrence of obstructing colon cancers after surgery for cure: a population- 
based study. Color Dis. 2013;15(9):1100-6 PubMed PMID: 23634749. Epub 2013/05/03. eng.

27. Nojiri T, Maeda H, Takeuchi Y, Funakoshi Y, Kimura T, Maekura R, et al. Predictive value of B-type natriuretic peptide for postoperative atrial fibrillation following pulmonary resection for lung cancer. Eur J Cardiothorac Surg. 2010;37(4):787-91 PubMed PMID: 19896864. Epub 2009/ $11 / 10$. eng.

28. Nojiri T, Inoue M, Yamamoto K, Maeda H, Takeuchi Y, Funakoshi Y, et al. Btype natriuretic peptide as a predictor of postoperative cardiopulmonary complications in elderly patients undergoing pulmonary resection for lung cancer. Ann Thorac Surg. 2011;92(3):1051-5 PubMed PMID: 21871299. Epub 2011/08/30. eng.

29. Cowie MR, Struthers AD, Wood DA, Coats AJ, Thompson SG, Poole-Wilson $P A$, et al. Value of natriuretic peptides in assessment of patients with possible new heart failure in primary care. Lancet. 1997;350(9088):1349-53 PubMed PMID: 9365448. Epub 1997/11/20. eng.

30. Cuthbertson BH, Card G, Croal BL, McNeilly J, Hillis GS. The utility of B-type natriuretic peptide in predicting postoperative cardiac events and mortality in patients undergoing major emergency non-cardiac surgery. Anaesthesia. 2007;62(9):875-81 PubMed PMID: 17697212. Epub 2007/08/19. eng.

31. Sabbagh C, Browet F, Diouf M, Cosse C, Brehant O, Bartoli E, et al. Is stenting as "a bridge to surgery" an oncologically safe strategy for the management of acute, left-sided, malignant, colonic obstruction? A comparative study with a propensity score analysis. Ann Surg. 2013;258(1): 107-15 PubMed PMID: 23324856. Epub 2013/01/18. eng.

32. Tung KL, Cheung HY, Ng LW, Chung CC, Li MK. Endo-laparoscopic approach versus conventional open surgery in the treatment of obstructing left-sided colon cancer: long-term follow-up of a randomized trial. Asian J Endosc Surg. 2013;6(2):78-81 PubMed PMID: 23601995. Epub 2013/04/23. eng.

33. Gianotti L, Tamini N, Nespoli L, Rota M, Bolzonaro E, Frego R, et al. A prospective evaluation of short-term and long-term results from colonic stenting for palliation or as a bridge to elective operation versus immediate surgery for large-bowel obstruction. Surg Endosc. 2013;27(3):832-42 PubMed PMID: 23052501. Epub 2012/10/12. eng.

34. Yang SY, Park YY, Han YD, Cho MS, Hur H, Min BS, et al. Oncologic outcomes of self-expandable metallic stent as a bridge to surgery and safety and feasibility of minimally invasive surgery for acute malignant colonic obstruction. Ann Surg Oncol. 2019;26(9):2787-96 PubMed PMID: 30989498. Epub 2019/04/17. eng.

35. van Hooft JE, van Halsema EE, Vanbiervliet G, Beets-Tan RG, DeWitt JM, Donnellan F, et al. Self-expandable metal stents for obstructing colonic and extracolonic cancer: European Society of Gastrointestinal Endoscopy (ESGE) clinical guideline. Endoscopy. 2014;46(11):990-1053 PubMed PMID: 253256 82. Epub 2014/10/18. eng.

36. Ansaloni L, Andersson RE, Bazzoli F, Catena F, Cennamo V, Di Saverio S, et al. Guidelenines in the management of obstructing cancer of the left colon: consensus conference of the world society of emergency surgery (WSES) and peritoneum and surgery (PnS) society. World J Emerg Surg. 2010;5:29 PubMed PMID: 21189148. Pubmed Central PMCID: PMC3022691. Epub 2010/12/30. eng.

37. Arezzo A, Balague C, Targarona E, Borghi F, Giraudo G, Ghezzo L, et al. Colonic stenting as a bridge to surgery versus emergency surgery for malignant colonic obstruction: results of a multicentre randomised controlled trial (ESCO trial). Surg Endosc. 2017;31(8):3297-305 PubMed PMID: 27924392. Epub 2016/12/08. eng

38. Amelung FJ, Burghgraef TA, Tanis PJ, van Hooft JE, Ter Borg F, Siersema PD, et al. Critical appraisal of oncological safety of stent as bridge to surgery in left-sided obstructing colon cancer; a systematic review and meta-analysis. Crit Rev Oncol Hematol. 2018;131:66-75 PubMed PMID: 30293707. Epub 2018/10/09. eng.

39. Domingo S, Puertolas S, Gracia-Villa L, Puertolas JA. Mechanical comparative analysis of stents for colorectal obstruction. Minim Invasive Ther Allied Technol. 2007;16(2):126-36 PubMed PMID: 17474056. Epub 2007/05/03. eng.

40. Suzuki N, Saunders BP, Thomas-Gibson S, Akle C, Marshall M, Halligan S. Colorectal stenting for malignant and benign disease: outcomes in colorectal stenting. Dis Colon Rectum. 2004;47(7):1201-7 PubMed PMID: 15164246. Epub 2004/05/28. eng.

41. Voutouri C, Mpekris F, Papageorgis P, Odysseos AD, Stylianopoulos T. Role of constitutive behavior and tumor-host mechanical interactions in the state of stress and growth of solid tumors. PLoS One. 2014;9(8):e104717
PubMed PMID: 25111061. Pubmed Central PMCID: PMC4128744. Epub 2014/08/12. eng.

42. Karagiannis GS, Poutahidis T, Erdman SE, Kirsch R, Riddell RH, Diamandis EP. Cancer-associated fibroblasts drive the progression of metastasis through both paracrine and mechanical pressure on cancer tissue. Mol Cancer Res. 2012;10(11):1403-18 PubMed PMID: 23024188. Pubmed Central PMCID: PMC4399759. Epub 2012/10/02. eng.

43. Maruthachalam K, Lash GE, Shenton BK, Horgan AF. Tumour cell dissemination following endoscopic stent insertion. Br J Surg. 2007;94(9): 1151-4 PubMed PMID: 17541987. Epub 2007/06/02. eng.

44. Matsuda A, Miyashita M, Matsumoto S, Sakurazawa N, Kawano Y, Yamahatsu $\mathrm{K}$, et al. Colonic stent-induced mechanical compression may suppress cancer cell proliferation in malignant large bowel obstruction. Surg Endosc. 2019;33(4):1290-7 PubMed PMID: 30171397. Epub 2018/09/02. eng.

45. Haraguchi $\mathrm{N}$, Ikeda M, Miyake M, Yamada T, Sakakibara Y, Mita E, et al. Colonic stenting as a bridge to surgery for obstructive colorectal cancer: advantages and disadvantages. Surg Today. 2016;46(11):1310-7 PubMed PMID: 27048552. Epub 2016/04/07. eng.

46. Zhu Z, Li B, Liao W, Lv N, Chen Y, Shu X. Novel predictive Nomogram for identifying difficult Guidewire insertion in patients with malignant colorectal obstruction and Sphincterotome-assisted Guidewire insertion for improving the success rate of self-expandable metal stent insertion. Front Oncol. 2020; 10:637 PubMed PMID: 32477935. Pubmed Central PMCID: PMC7237730. Epub 2020/06/02. eng.

47. Miyasako Y, Kuwai T, Ishaq S, Tao K, Konishi H, Miura R, et al. Newly developed self-expandable Niti-S MD colonic metal stent for malignant colonic obstruction. World J Gastrointest Surg. 2020;12(4):138-48 PubMed PMID: 32426093. Pubmed Central PMCID: PMC7215972. Epub 2020/05/20. eng.

\section{Publisher's Note}

Springer Nature remains neutral with regard to jurisdictional claims in published maps and institutional affiliations.
Ready to submit your research? Choose BMC and benefit from:

- fast, convenient online submission

- thorough peer review by experienced researchers in your field

- rapid publication on acceptance

- support for research data, including large and complex data types

- gold Open Access which fosters wider collaboration and increased citations

- maximum visibility for your research: over $100 \mathrm{M}$ website views per year

At BMC, research is always in progress.

Learn more biomedcentral.com/submissions 